\title{
ИЗУЧЕНИЕ ГИПОГЛИКЕМИЧЕСКОЙ АКТИВНОСТИ СТРУКТУРНЫХ АНАЛОГОВ ФЕНИЛПРОПАНОВОЙ КИСЛОТЫ
}

\author{
Д.А. Кузнецова, М.В. Хвостов, С.О. Куранов, О.А. Лузина, \\ Т.Г. Толстикова, Н.Ф. Салахутдинов
}

Новосибирский институт органической химии им. Н. Н. Ворожцова СО РАН, 630090, Россия г. Новосибирск, просп. Академика Лаврентьева, д.9.

DOI: 10.19163/MedChemRussia2021-2021-371_E-mail:kuznetsova@nioch.nsc.ru

Одним из наиболее распространённых хронических заболеваний в настоящее время является сахарный диабет 2 типа (СД2), поскольку им страдают примерно 460 миллионов человек [1]. К тому же, терапия СД2 нуждается в улучшении, т.к. каждый класс гипогликемических препаратов имеет свои побочные эффекты [1]. Следовательно, эти факторы обуславливают поиск новых гипогликемических средств. Одним из направлений поиска является разработка агонистов рецептор свободных жирных кислот - 1 (FFAR1) которые стимулируют секрецию инсулина глюкозо-зависимым образом [2]. Ранее было показано, что соединение 1, совмещающее в своей структуре фрагмент фенилпропановой кислоты (ФПК) с фрагментом, полученным из камфоры, проявляет активность в тестах in vitro и обладает гипогликемическим эффектом в тесте in vivo на мышах [3].

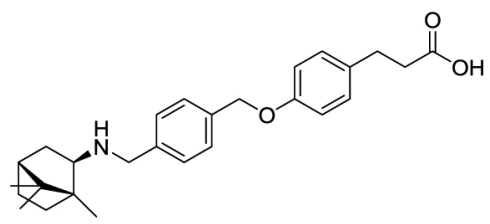

1<smiles>CC1(C)C(OCc2ccc(COc3ccc(CCC(=O)O)cc3)cc2)[C@H]2CC[C@@H]1C2(C)C</smiles>

В данной работе мы исследовали гипогликемические свойства новых структурных аналогов соединения 1, в которых варьировался терпеновый фрагмент. Для выявления гипогликемической активностью был использован оральный глюкозотолерантный тест (ОГТТ), с помощью которого было обнаружено, что соединение 2, содержащее борнильный фрагмент, дозозависимо снижает уровень глюкозы после перорального введения в дозах 10 и 30 мг/кг. Далее соединения 1 и 2 исследовали на животной модели СД2 (мыши линии C57BL/6Ау) в дозе 30 мг/кг в течение 2-х недель. По окончанию эксперимента соединение 2 проявило гипогликемический эффект. При проведении биохимического исследования крови и гистологического исследования печени животных было выявлено, что введение 1 способствует нормализации липидного обмена, а также приводит к разрешению жировой дистрофии печени, которая является типичной для этой линии животных.

\section{Литература}

[1] Joseph M. Pappachan, et al. Molecular Aspects of Medicine, 2019, 66, 3-12.

[2] Hara T. Handbook of Experimental Pharmacology, 2017, 236, 1-16.

[3] Sergey O. Kuranov, et al. Bioorganic Chemistry, 2020, 99, 103830. 